\title{
INFORMATION REUSE IN SMART CITIES' ECOSYSTEMS
}

\author{
Reutilización de información en las ciudades inteligentes
}

\author{
Alberto Abella, Marta Ortiz-de-Urbina-Criado and Carmen De-Pablos- \\ Heredero
}

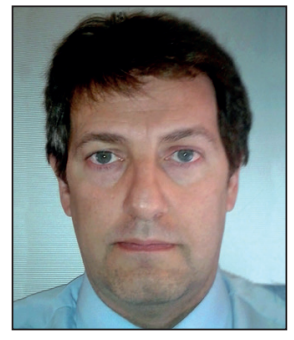

Alberto Abella is a telecommunications engineer, assistant professor at Universidad Rey Juan Carlos and a PhD student at Escuela Internacional de Doctorado in the program of Social and legal sciences at Universidad Rey Juan Carlos. He is an expert in open data and open government within public and private sectors. He is president of the Spanish chapter of Open Knowledge Foundation. http://orcid.org/0000-0003-0243-4606

alberto.abella@meloda.org

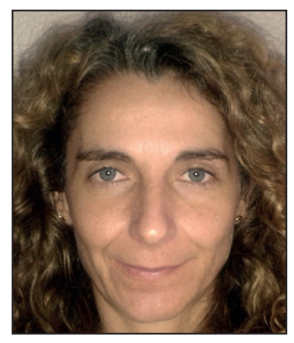

Marta Ortiz-de-Urbina-Criado, PhD in economics and business administration science, is an associate professor at University Rey Juan Carlos, Madrid. She has published articles in impact journals as International business review, International journal of technology management, Journal of knowledge management, El profesional de la información, and Revista española de financiación y contabilidad.

http://orcid.org/0000-0001-7527-6798

marta.ortizdeurbina@urjc.es

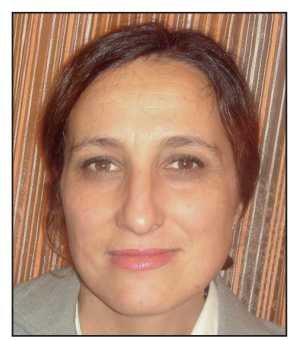

Carmen De-Pablos-Heredero has a PhD in economics and business administration science. She is an associate professor, head of the Master degree in business organization at University Rey Juan Carlos, Madrid. She has published articles in impact journals as CEDE, Universia, Interciencia, TIBE, Journal of entrepreneurship management, International journal of marketing research, Social sciences journal, World economy, Dyna, Pensée, El profesional de la información, and REIS. http://orcid.org/0000-0003-0457-3730

carmen.depablos@urjc.es

Universidad Rey Juan Carlos, Facultad de Ciencias Jurídicas y Sociales Paseo de los Artilleros, s/n. 28032 Madrid, España

\begin{abstract}
Smart cities are service providers as well as sources of public data. The reuse of cities' data through the application of technology enables the creation of innovative services for citizens. Apps, developed by reusing information, are considered a key indicator for the creation of services. This paper explores the main characteristics of these apps and their relationship to services. The analysis performed in the main smart cities in Europe shows the importance of timely information release and the geo-location of published data. Transport and tourism seem to be the most popular areas of application. This article builds on the area of research in previous studies and includes additional information of apps' characteristics to meet service needs.
\end{abstract}

\section{Keywords}

Information reuse; Smart cities; Datasets; Applications; Apps; Open government.

\section{Resumen}

Las ciudades inteligentes son fuentes de datos públicos, los cuales, debidamente tratados mediante tecnologías pueden reutilizarse creando servicios innovadores para los ciudadanos. Las aplicaciones desarrolladas a este fin son un indicador para evaluar el nivel de creación de tales servicios, por lo que en este trabajo se analizan sus características. El análisis realizado en las principales ciudades inteligentes en Europa revela la importancia de la actualización de la información y de la geolocalización de los datos publicados. También se observa que los temas más populares son el transporte y el turismo. Este trabajo mejora la explicación de los resultados obtenidos en esos otros estudios previos e incluye información sobre otras importantes características de las aplicaciones. 


\section{Palabras clave}

Reutilización; Ciudades inteligentes; Conjuntos de datos; Aplicaciones; Apps; Gobierno abierto.

Abella, Alberto; Ortiz-de-Urbina-Criado, Marta; De-Pablos-Heredero, Carmen (2015). "Information reuse in smart cities' ecosystems". El profesional de la información, v. 24, n. 6, pp. 838-844.

http://dx.doi.org/10.3145/epi.2015.nov.16

\section{Introduction}

The open data movement promotes the release of government data (Peset; Ferrer-Sapena; Subirats-Coll, 2011) and makes these available to the public, by means of what is called open government data. Hence, anyone or any organization could create new information and services using available data (Marcos-Martin; Soriano-Maldonado, 2011). The reuse of Public Sector Information (PSI) has an economic impact that has been extensively analyzed by various institutions with very different results; in the EU, figures range from $0.25 \%$ of GDP (Dekkers et al., 2006) to 1.7\% GDP (Vickery, 2011). It is indisputable that smart cities offer considerable potential.

Today smart city portals offer a lot of public information through catalogs. These catalogs provide access to sources of information that can be used to create new services by the private and public sectors. They became valuable sources for the creation of big data business (LaValle et al., 2011; Kitchin, 2014; Abella; Ortiz-de-Urbina-Criado; De-PablosHeredero, 2014). Smart cities are generating and compiling extensive data produced as a consequence of their sensoring capabilities, the dynamic of their internal processes, and the implementation of collaborative tools. The current trend is to publish these data in reusable streams and datasets thereby encouraging its ecosystem (citizens, private companies, and social organizations) to create new and innovative services based on the data. In this context some of these added-value services include an external data fee, while others are free.

\section{A smart city is an entity that provides services directly to the citizens through its own resources or by subcontracting needed resources}

Smart city is the key concept to cope with some of the biggest challenges in our society, not just overpopulation, but also transportation, pollution, sustainability, security, health, and business generation. Citizens demand better levels of services which in turn requires increasing public resources. Furthermore, cities need to cope with the increasing demand for citizen participation (Ramírez-Alujas; Dassen, 2014). So, on the one hand smart cities are depicted as one of most promising environments for open innovation, but on the other hand they are also one of the most demanding environments for the enrichment of public administration services.

In order to analyze this situation, smart cities can be mo- delled as data sources and service providers' ecosystems: populated by a main agent, the city, and shared with other members such as companies, developers, and NGOs who will reuse a city's information. All are enabled by technology to create innovative services for citizens. Apps that reuse information have been chosen as the key indicator for the creation of services. Therefore, the objective of this paper is to explore the information shared and the generated apps in smart cities with the intention of characterizing those ecosystems.

\section{Smart cities}

\subsection{Smart city's concept}

Smart city is a broad and variable concept (Nam; Pardo, 2011). According to Hall (2000), a smart city is:

"a city that monitors and integrates conditions of all of its critical infrastructures, including roads, bridges, tunnels, rails, subways, airports, seaports, communications, water, power, event major buildings, can better optimize its resources, plan its preventive maintenance activities and monitor security aspects while maximizing services to its citizens".

According to Giffinger et al. (2007) a smart city is:

"a city well performing in a forward-looking in economy, people, governance, mobility, environment, and living built on the smart combination of endowments and activities of self-decisive independent and aware citizens".

Based on Washburn et al. (2010) a smart city is:

"the use of smart computing technologies to make the critical infrastructure components and services of a city -which include city administration, education healthcare, public safety, real estate, transportation and utilities- more intelligent, interconnected and efficient".

According to these definitions a smart city is a public-private ecosystem providing services to citizens and their organizations with the strong support of technology. From a comparison of smart cities three remarkable approaches have been identified:

- Sustainable smart city: One of the most popular approaches to smart cities consists of a consideration of their energy consumption. In this approach much of the attention is paid to energy savings, alternative energy sources, and more efficient transport means. The main advantage of this approach is the easy translation of the investments into money savings. 
- Sensored smart city: In this approach an emphasis is put on the sensoring of the city. A city scatters thousands of different sensors such as traffic sensors, air pollution sensors, sound sensors, humidity sensors, and cameras sensors. These sensors provide critical information for tackling some of the most demanding challenges of the city. However, managing the impressive amount of data generated defies current available technology. Utilizing sensors to their full potential may provide logical insight into some of the toughest problems of the city at the cost of maintaining a complex technical infrastructure.

- Collaborative smart city: A third and popular approach to the smart city is the one which builds on the ability of its citizens to participate in the daily operations of the city. Digital participation mechanisms, data (sensoring)

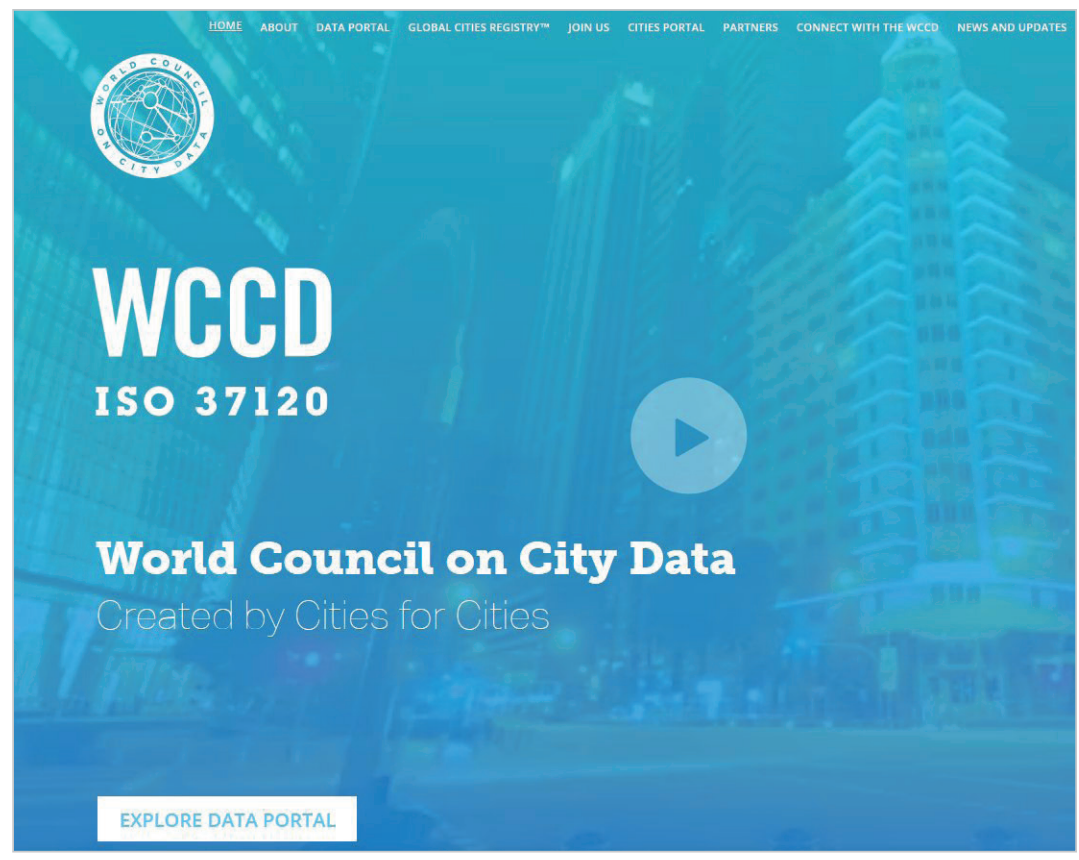

http://www.dataforcities.org provided to citizens contribute to the improvement of such operations as city management, participative budgets. Although, in this approach, simple technical tools are found, it requires complex implementation strategies due to the difficulties that emerge from massive participation in any organization.

Holistically combining these three smart city approaches and some other dimensions could be a way to find solutions to the many challenges of our society. By definition resources are scarce, therefore, in every case a holistic approach can help determine which aspect of the smart city should be developed first and which one deserves the biggest portion of available resources.

\subsection{Smart cities as service providers}

A smart city is an entity that provides services directly to the citizens through its own resources or by subcontracting needed resources. This approach is no different from what cities have been doing for centuries. It is true that technology is being used differently when compared to the past; however, from a qualitative point-of-view a city manages its resources in much the same way as it did previously. And, a second approach allows smart cities to make it easy for people to reuse some of the released digital assets (datasets, data streams, and other digital resources) and provide complementary services. However, when the two approaches are compared in

Table 1. Smart city services classification

\begin{tabular}{|l|l|}
\hline & \\
Energy & Ecommerce \\
Transport and mobility & Education and culture \\
Health services & Urban infrastructure, public buil- \\
Governance and citizens & dings and housing \\
Environmental sustainability & Communications \\
Water and gas & Security \\
& Leisure and digital tourism \\
\hline
\end{tabular}

Source: Ametic (2014)

terms of invested resources versus services provided, the scales are tipped in favor of the second approach. It is also true that the second approach cannot be used for all services, but with increases in available digital technology, what formerly was an impossible approach can now be considered feasible.

In order to analyze these services some existing standardized categories have been taken into consideration. According to Ametic (2014), the smart city services are classified into 12 categories (table 1 ).

At an international level there is also considerable concern about the services that a smart city delivers to its citizens and how they impact their living standards. This concern is expressed by organizations and appears in publications such as those of the World Council on City Data, organization that leads the global implementation of ISO 37120. In this standard, smart city indicators are classified in two groups -city services and quality of life- (table 2). It comprises 21 categories and 100 indicators.

\section{Smart cities' apps}

For the exploratory analysis, sampling between some of the main cities of the European Union (EU) belonging to an EU wide city association was carried out (December 2014). http://eurocities.eu

Table 2. Smart city services classification

\begin{tabular}{|ll|l|}
\hline \multicolumn{2}{|c|}{ City services } & \multicolumn{1}{c|}{ Quality of life } \\
\hline \multirow{2}{*}{ Education } & Energy & Civic engagement \\
Finance & Recreation & Culture \\
Fire emergency & Response & Economy \\
Governance & Health & Environment \\
Safety & Solid waste & Shelter \\
Transportation & Urban planning & Social equity \\
Waste water & Water & Technology \& innovation \\
& & \\
\hline
\end{tabular}

Source: ISO 37120 (2014) 


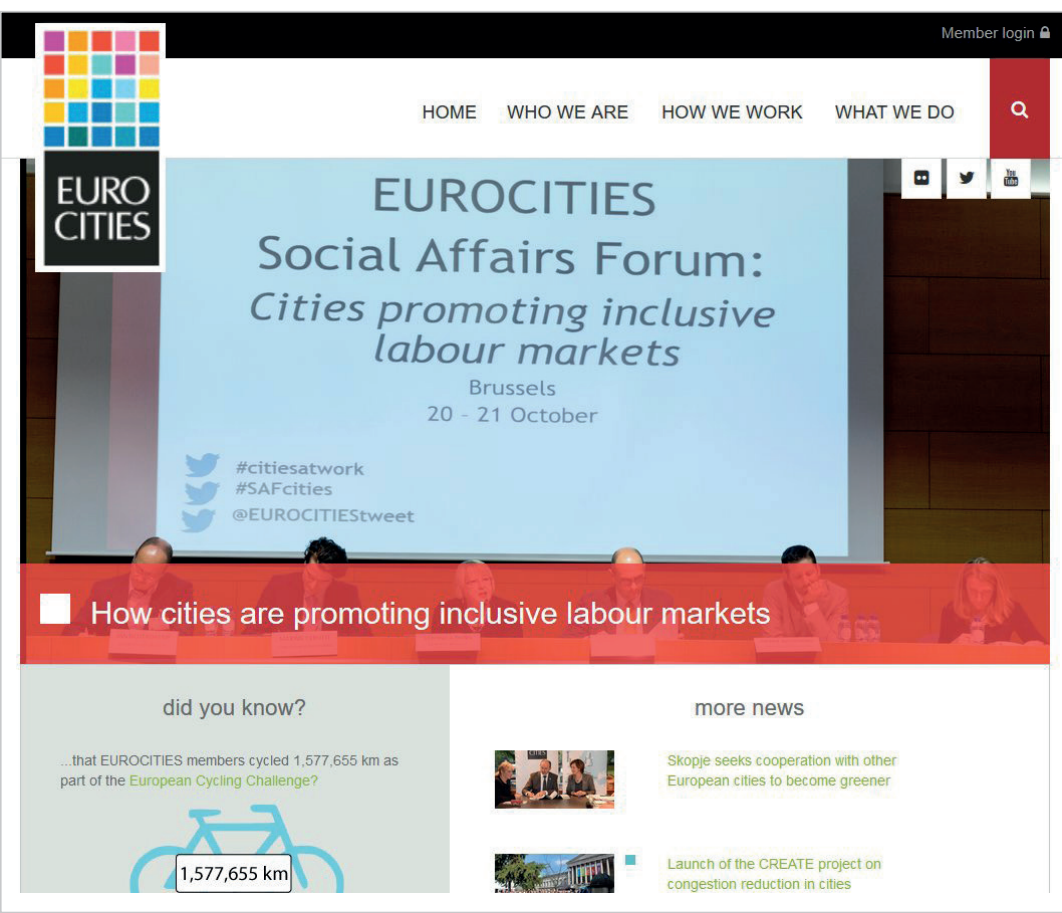

http://eurocities.eu

The analysis found two resources: 1) the cities' open data portal to identify those datasets with the biggest number of downloads; 2) the apps reusing smart city data. Sometimes these apps are listed in the same open data portal. Sometimes they are in specific smart city apps' portals. Although $90 \%$ of the sampled cities own an open data portal for the city, only $60 \%$ of the overall total have built a specific portal/ section in the city's website dedicated to the applications created based on the smart city data as described in table 3.

Mobile and web apps have been chosen as indicators of the reuse of smart cities' information and therefore as an indicator of innovative services for several reasons. First, their low cost of development -they are available in almost every smart city. Second reason is their global availability for end users through the smart city apps portals or the mobile apps stores. Third, apps can potentially reuse any information released by the city. Finally, an easy basic monetization mechanism through the app stores is provided.

Smart cities' portals often show sections compiling apps based on data released by the city. However, the term app could lead us to consider very different applications; from just simple apps which are installed through the most po-

Table 3. Sampled cities and apps

\begin{tabular}{|c|l|c|l|}
\hline Number of apps & \multicolumn{1}{|c|}{ Cities (country) } & Number of apps & \multicolumn{1}{c|}{ Cities (country) } \\
\hline 110 & Helsinki (Finland) & 22 & Amsterdam (Netherlands) \\
\hline 52 & London (United Kingdom) & 22 & Liverpool (United Kingdom) \\
\hline 35 & Bologne (Italy) & 4 & Marseille (France) \\
\hline 33 & Zaragoza (Spain) & 4 & Milano (Italy) \\
\hline 33 & Zurich (Switzerland) & 3 & Malaga (Spain) \\
\hline 24 & Berlin (Germany) & 2 & Strasbourg (France) \\
\hline
\end{tabular}

Cities lacking a section for apps using open data portal: Frankfurt, Düsseldorf, Nuremberg, Paris, Lyon, Florence, Manchester and Brighton pular app markets, to web services accessed via mobile or desktop, or apps which compile lots of services. In this paper, the focus will be on the simplest apps or web services. They can be clearly identified with one and less than three single data streams. When there is no such portal, only those apps officially backed by the city are considered for the sampling.

For the purpose of this article, information will also be qualified according to three metadata. The first metadata is information type and it will be classified into seven categories according to the Mepsir classification (Dekkers et al., 2006). Further explanations are included in table 4. The second metadata is the updating characteristics of the information. Real time data are released 'as soon as' they are generated. It does not mean that it should be released in seconds after generation (some processes can take weeks, months, etc.) but this often happens this way. And third metadata refers to the geolocation characteristics of the data. Thus it is possible to group data based on their location, for example in districts, or zip codes.

The main objective of this article is to analyse smart cities as service providers and public data sources

For an exploratory analysis, 25 apps from nine smart cities (located in Germany, Italy, France, The Netherlands, and the United Kingdom) were analyzed. Table 5 shows some of the characteristics found in these apps using categories of topics including (referring to the type of information used for the services provided by the app) author/creator, real-time, and geolocation features.

It was found that transport and traffic are the most recurrent topics (37\%) followed by other information (26\%). Note that an application could use a type of information, as for example, demography, which belongs to the social type of information, but also provides traffic forecasts. The most popular datasets include transport and traffic, matching the apps trend, but they also include social information.

Tourist information is one of the most popular topics within the category of 'other information'. Geographic is a topic which accounts for $19 \%$ of the overall apps. Commonly these geographic apps are street maps and other kinds of enriched maps. 
Table 4. Classification of information

\begin{tabular}{|c|c|}
\hline Type & Definition \\
\hline Business & $\begin{array}{l}\text { Data related to the surrounding economy. It does not include data related to the investments, expenses, etc., generated by } \\
\text { the own public body (included in legal category). } \\
\text { Global economy indicators are included in this type of information. }\end{array}$ \\
\hline Geographical & Most of the data containing georeferenced (maps). It does not include other information concerning to geolocation. \\
\hline Legal & $\begin{array}{l}\text { Includes not only data about the legal activities of entities but also data related to investments, expenses, bidding, etc., of } \\
\text { public entities. }\end{array}$ \\
\hline Meteo & Data related to the weather and environmental information related to the area. \\
\hline Social and statistical & $\begin{array}{l}\text { Data related to society which surrounds entity i.e. demography, social behavior, etc. And that information is freely shared } \\
\text { between users. }\end{array}$ \\
\hline Transport/Traffic & Data related to traffic and transport by any means, flight, road, railway, etc. \\
\hline Other & Data not included in the other categories, for example cultural information, agenda, tourism, etc. \\
\hline
\end{tabular}

Source: Based on Dekkers et al. (2006)

However, social, meteorological (meteo), and business topics represent a small percentage of the sampled apps (4\%). In the case of legal topic, no apps were found.

\section{The fact that the biggest percentage of} the apps in existing portals has been developed by the own city could confirm that the ecosystems around these cities are in its early stages

When it was possible to identify the author/creator, it was also found that the majority of the apps were developed by the city or other public organization (45\%). Apps created by public organizations are the most popular in the newest portals. Individual developers represent $27 \%$ of the apps' authors. In the latter case, apps are frequently created as part of promotional events for the portals (hackatons). Private businesses, mostly small and medium firms, only developed $14 \%$ of the apps and another $14 \%$ of the authors could not be identified.

Geolocation is a feature found in all the most downloaded sampled apps. However, geolocation is only present in $74 \%$ of the overall sampled apps. The real-time feature is less popular than geolocation, found in only $61 \%$ of the sampled apps.

Another finding about the sampled apps is the lack of information in city portals about apps' characteristics such as the number of downloads, number of versions, last update date, and users' opinions (table 5). The number of downloads is a key parameter to understand the impact of the app. Availability of that information would help to understand the liveliness of the app. Therefore, providing this data would let us analyze the activity of the smart city ecosystem.

It is noteworthy in the sampled apps that licensing conditions tend to be compatible with the open definition:

OKFN (Open Knowledge Foundation). Open definition, Oct. 2014.

http://opendefinition.org

It is equivalent to CC-BY 0 or CC-BY-SA, but with specific license conditions coming from public administrations. Apart from this, the most popular access mechanism to the catalog is provided by CKAN (Comprehensive Knowledge Archive Network). However, customization on CKAN platform (it is an open source solution) restricts the automatic access to some interesting metadata as downloads.

http://ckan.org

Table 5. Characteristics of the apps

\begin{tabular}{|l|c|l|c|c|c|}
\hline \multicolumn{1}{|c|}{ Topic } & \% & \multicolumn{1}{c|}{ Authors } & \% apps' & Geolocated \\
\hline Transport/Traffic & 37 & Public entity & 45 & Yes \\
\hline Other & 26 & Developer & 27 & No \\
\hline Geographic & 19 & Business & 14 & Other characteristics & \% available apps' info \\
\hline Social & 11 & No identity & 14 & Number of downloads \\
\hline Meteo & 4 & Real time & \% apps & Number of versions \\
\hline Business & 4 & Yes & 61 & Last update date \\
\hline Legal & 0 & No & 39 & User's opinion \\
\hline
\end{tabular}




\section{Conclusions}

Smart cities' ecosystems have been found to be in their early stages of development. Those portals having less than five apps could be grouped into this category. Only eight out of the 31 sampled smart cities exceeded five apps in their portal.

Smart cities' release of information is one of the most promising and complex fields to study the value creation and the impact of open data. This article continues the research area started in previous analyses on smart cities as service providers and public data sources (Abella; Ortiz-de-UrbinaCriado; De-Pablos-Heredero, 2015 a; b). Several contributions are presented. First, a more detailed analysis of the theoretical framework has been provided. Second, further explanations about data sources' topic classification and apps' data consumption have been included. Third, apps' authors/creators have been analyzed. And lastly, an analysis of new characteristics of apps (number of downloads, number of versions, last update date, and users opinions) has also been included.

Smart cities' release of information is one of the most promising and complex fields to study the value creation and the impact of open data.

The first remarkable finding is that the most frequent topics in popular datasets are transport and traffic. Social information, describing information about accidents, diseases, demography, etc., is the second most popular topic. Moreover, results have shown that geolocation and real time characteristics of the information play an important role in its reuse. Geolocation information is found in all of the most downloaded datasets. Finally, approximately half of the sampled apps were developed by the city.

An element to be addressed in further research is the return on investment (ROI) for the city (economic and social) and how the ecosystem of reusers helps themselves and the city to create sustainable business models. A more exhaustive sampling of data together with some modelling are expected to lead us to more precise conclusions on these matters.

In a smart city it is now possible to tailor the design and delivery of services in a way that meets the specific demands and preferences of different population segments, specific situations, and even individual citizen's needs. Therefore, an interesting area for future research is the study of the citizen's experience within smart cities' services.

\section{Acknowledgements}

To Dr. Rozz Albon for helping us with the linguistic revision. This article has been financed by the Ministry of Economy and Competitiveness (Spain), project ECO201236775, and the Rey Juan Carlos University-Santander Bank Strategor Research Excellence Group.

\section{References}

Abella, Alberto; Ortiz-de-Urbina-Criado, Marta; De-PablosHeredero, Carmen (2014). "Meloda, a metric to assess open data reuse". El profesional de la información, v. 23, n. 6, pp. 582-588.

http://dx.doi.org/10.3145/epi.2014.nov.04

Abella, Alberto; Ortiz-de-Urbina-Criado, Marta; De-PablosHeredero, Carmen (2015a): "Smart cities' datasets and applications ecosystem: An exploratory analysis". In: Peter Parycek; Noella Edelmann (editors): CeDem15 - Procs of the Int conf for e-democracy and open government 2015, Edition Donau-Universität Krems, pp. 319-325.

http://goo.gl/vONUHO

Abella, Alberto; Ortiz-de-Urbina-Criado, Marta; De-PablosHeredero, Carmen (2015b): "The ecosystem of services around smart cities: An exploratory analysis". In: Centeris - Conf on enterprise information systems, Vilamoura, Procedia computer science, v. 64C, pp. 1076-1081.

http://dx.doi.org/10.1016/j.procs.2015.08.554

Ametic (2014). Clasificación por sectores de servicios y aplicaciones para la smart city. Grupo de trabajo smart cities. Internal document.

Dekkers, Makx; Polman, Femke; Te Velde, Robbin; De Vries, Marc (2006). Mepsir (Measuring European public sector information resources). Final report of study on exploitation of public sector information - benchmarking of EU framework conditions, Executive summary and final report.

http://goo.gl/HD5ONi

Giffinger, Rudolf; Fertner, Christian; Kramar, Hans; Kalasek, Robert; Pichiler-Milanoviu, Nataša; Meijers, Evert (2007). Smart cities: Ranking of European medium-sized cities. Vienna, Austria: Centre of Regional Science (SRF), Vienna University of Technology.

http://goo.gl/LcJyz

Hall, Robert E. (2000). "The vision of a smart city". In: Procs of the $2^{\text {nd }}$ Intl life extension technology workshop. Paris, France, Sept. 28. http://goo.gl/qYnbOb

Kitchin, Rob (2014). "The real-time city? Big data and smart urbanism". GeoJournal, February, v. 79, pp. 1-14. http://link.springer.com/article/10.1007\%2Fs10708-013-9516-8

LaValle, Steve; Lesser, Eric; Shockley, Rebecca; Hopkins, Michael S.; Kruschwitz, Nina (2011). "Big data, analytics and the path from insights to value". MIT Sloan management review, January, v. 52, n. 2, pp. 21-32.

http://sloanreview.mit.edu/article/big-data-analytics-andthe-path-from-insights-to-value

Marcos-Martín, Carlos; Soriano-Maldonado, Salvador-Luis (2011). "Reutilización de la información del sector público y open data en el contexto español y europeo. Proyecto Aporta". El profesional de la información, mayo-junio, v. 20, n. 3, pp. 291-297.

http://dx.doi.org/10.3145/epi.2011.may.07 
Nam, Taewoo; Pardo, Theresa A. (2011). “Conceptualizing smart city with dimensions of technology, people, and institutions". In: Proceedings of the $12^{\text {th }}$ Annual intl conf on digital government research, pp. 282-291.

http://goo.gl/GS47AS

Peset, Fernanda; Ferrer-Sapena, Antonia; Subirats-Coll, Imma (2011). "Open data y linked open data: su impacto en el área de bibliotecas y documentación”. El profesional de la información, marzo-abril, v. 20, n. 2, pp. 165-173.

http://dx.doi.org/10.3145/epi.2011.mar.06

Ramírez-Alujas, Álvaro V.; Dassen, Nicolás (2014). “Vientos de cambio: El avance de las políticas de gobierno abierto en América Latina y el Caribe". Banco Interamericano de Desarrollo. Nota técnica \# idb-tn-629.

http://bit.ly/ramirez2014

Schaffers, Hans; Komninos, Nicos; Pallot, Marc; Trous- se, Brigitte; Nilsson, Michael; Oliveira, Alvaro (2011). "Smart cities and the future internet: Towards cooperation frameworks for open innovation". In: Domingue et al. (eds.): Future Internet Assembly, LNCS 6656, pp. 431446.

\section{http://goo.gl/OetW9B}

Vickery, Graham (2011). "Review of recent studies on PSI reuse and related market developments". Paris: Information Economics.

$h t t p: / / g o o . g l / v D S O z l$

Washburn, Doug; Sindhu, Usman; Balaouras, Stephanie; Dines, Rachel A.; Hayes, Nicholas M.; Nelson, Lauren E. (2010). Helping ClOs understand "smart city" initiatives: defining the smart city, its drivers, and the role of the $\mathrm{CIO}$. Cambridge, MA: Forrester Research, Inc.

http://goo.gl/4XHkOF

\section{No descuides mantener actualizados tus datos en el Directorio EXIT} (EXpertos en el Tratamiento de la Información)

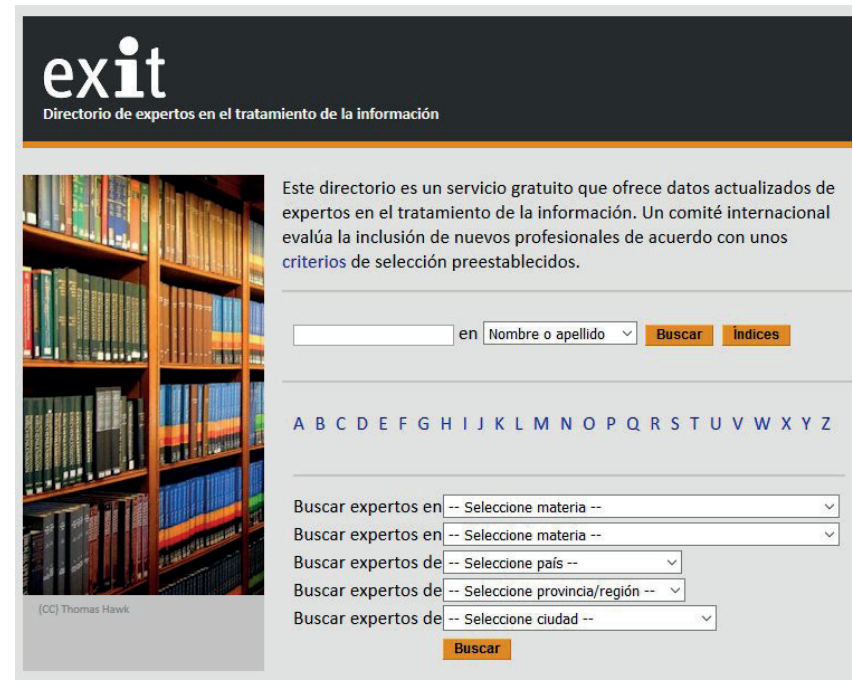

\begin{tabular}{|c|c|c|}
\hline \multirow[b]{2}{*}{ Países } & \multirow[b]{2}{*}{$n^{\circ}$} & A curriculum \\
\hline & & e. LiS 6 documents \\
\hline $\begin{array}{l}\text { España } \\
\text { Colombia }\end{array}$ & $\begin{array}{c}2.287 \\
187\end{array}$ & Q Gongle Citatione \\
\hline México & 126 & o Google Citations \\
\hline Argentina & 113 & M. Mendeley \\
\hline $\begin{array}{l}\text { Brasil } \\
\text { Reino Unido }\end{array}$ & $\begin{array}{c}107 \\
81\end{array}$ & \\
\hline Cuba & 72 & RG ResearchGate \\
\hline Perú & 69 & \\
\hline Chile & 68 & R ResearcherlD \\
\hline EUA & 61 & \\
\hline $\begin{array}{l}\text { Italia } \\
\text { Portugal }\end{array}$ & $\begin{array}{l}46 \\
40\end{array}$ & (iD) Orcid \\
\hline $\begin{array}{l}\text { Francia } \\
\text { Holanda }\end{array}$ & $\begin{array}{l}32 \\
30\end{array}$ & $\Phi^{+}$Google+ \\
\hline Ecuador & 28 & \\
\hline Venezuela & 21 & f Facebook \\
\hline Bélgica & 19 & \\
\hline Alemania & 17 & 9. Twitter \\
\hline Uruguay & 13 & \\
\hline Suiza & 12 & \\
\hline
\end{tabular}

Puedes incluir enlaces a tus páginas de las redes sociales (pon sólo la parte final de los urls)

\section{Especialidades más representadas en EXIT no}

Gestión de la información y del conocimiento 942 Web 2.0 y redes sociales $\quad 747$ Biblioteca universitaria $\quad 706$ Recuperación de información y búsquedas $\quad 636$ Información científico-técnica $\quad 577$ Biblioteca digital 550

Planificación y gestión 483

Bibl. especializada / Centro de documentación 454

Análisis y diseño de sistemas de información 453

Gestión de contenidos 437

Open access $\quad 427$

Comunicación 422

Catalogación, clasificación e indexación 401

Bases de datos (contenidos) 388

Educación, formación, alfin 337

Revistas electrónicas $\quad 335$

Bibliometría y cibermetría $\quad 324$

Marketing y promoción 317

Documentación en general $\quad 316$

Arquitectura de la información 311

Servicios de internet en general $\quad 297$

Información biomédica 290

Diseño de webs 284

Usabilidad, interfaces e interacción 274

Biblioteca pública $\quad 270$

Software documental 245

Ontologías, metadatos, taxonomías y tesauros 230

Periodismo 229

Multimedia y documentación audiovisual $\quad 229$

Información humanística 227

http://directorioexit.info 